\title{
Dynamics of Soil Nitrogen Availability Following Sunn Hemp Residue Incorporation in Organic Strawberry Production Systems
}

\author{
Jianyu Li and Xin Zhao \\ Horticultural Sciences Department, University of Florida, Gainesville, FL \\ Gabriel Maltais-Landry \\ Soil and Water Sciences Department, University of Florida, Gainesville, FL
}

Bodh R. Paudel

Horticultural Sciences Department, University of Florida, Gainesville, FL

Additional index words. anion exchange membrane, biomass, Crotalaria juncea, decomposition, early yield, Fragaria $\times$ ananassa Duch., $\mathrm{N}$ loss, $\mathrm{N}$ mineralization, $\mathrm{NO}_{3}-\mathrm{N}$, sandy soil

\begin{abstract}
Sunn hemp (Crotalaria juncea L.), as a summer leguminous cover crop, is often grown before fall planting of strawberries (Fragaria $\times$ ananassa Duch.) in Florida. Although sunn hemp has been suggested as a green manure for supplying nitrogen $(N)$ to subsequent crops, limited information is available regarding the contribution of sunn hemp biomass to soil $\mathbf{N}$ availability in Florida sandy soils with low levels of organic matter. This is especially true for organic strawberry production where nutrient management remains one of the major yield-limiting factors. This study was conducted in Citra, FL, and assessed the dynamics of $\mathrm{N}$ availability after soil incorporation of sunn hemp in organic strawberry production systems established on sandy soils in a subtropical environment. Sunn hemp was planted at a seeding rate of $44.9 \mathrm{~kg} \cdot \mathrm{ha}^{-1}$ on $19 \mathrm{July}$ 2017 and 24 July 2018 and terminated 65 days after seeding; a summer weedy fallow was used as the control. Containerized strawberry seedlings of Sweet Sensation ${ }^{\circledR}$ 'Florida127' were transplanted on 13 Oct. 2017 (22 days after sunn hemp incorporation) and 4 Oct. 2018 (8 days after sunn hemp incorporation). Immediately after sunn hemp incorporation, anion exchange membranes (AEMs) were buried in the soil to monitor soil $\mathrm{NO}_{3}-\mathrm{N}$ fluxes, together with traditional soil testing to measure extractable soil $\mathrm{NO}_{3}-\mathrm{N}$ concentrations. In the 2018 season, soils incorporated with sunn hemp residues were also incubated in the laboratory at $24^{\circ} \mathrm{C}$ over 8 weeks to determine the $\mathrm{N}$ release pattern by quantifying soil $\mathrm{NO}_{3}-\mathrm{N}$ and $\mathrm{NH}_{4}-\mathrm{N}$. Overall, nitrate fluxes monitored by AEMs in the first 3 weeks after sunn hemp incorporation were significantly higher in the sunn hemp treatment than in the weedy fallow control (by $66 \%$ to $185 \%$ ) in both years. Sunn hemp incorporation also led to a considerable increase in extractable soil $\mathrm{NO}_{3}-\mathrm{N}$ concentration (by $20 \%$ to $94 \%$ ). The early and fast release of plant available N (PAN) from sunn hemp residues was confirmed by the 8-week laboratory incubation study, which demonstrated that the net $\mathbf{N}$ mineralization rate of sunn hemp remained highest over the first 2 weeks of the incubation period. Sunn hemp showed a positive impact on organic strawberry earlyseason fruit yield in both years, with significant increases in marketable (by 59\%) and total (by 52\%) fruit weight yields and marketable fruit number (by 46\%) in 2017 and total fruit number (by 15\%) and weight yield (by 14\%) and marketable fruit number (by $13 \%$ ) in 2018. Given the typical waiting period between sunn hemp residue soil incorporation and strawberry planting as well as the lag in nutrient uptake shortly after transplanting, a large fraction of $\mathrm{N}$ released from sunn hemp residues is likely not taken up by strawberry plants. Our findings highlight the challenges of using sunn hemp residues to improve $\mathrm{N}$ availability for meeting crop demand and enhance fruit yield in organic strawberry production while minimizing environmental $\mathbf{N}$ losses in Florida sandy soils.
\end{abstract}

Florida is the second leading producer of organic strawberries (Fragaria xananassa Duch.) in the United States, with a focus on winter season production (USDA-NASS, 2017). Ensuring nitrogen (N) supply meets crop demands throughout the crop cycle remains a major challenge in organic production systems (Gaskell and Smith, 2007), and this could be exacerbated in Florida, where soils at most production sites have a high organic fertilizers and SOM (Cherr et al., 2007). Integrating cover crops into crop rotation may help build SOM while improving other soil characteristics for crop nutrient management (Haruna and Nkongolo, 2015; Thorup-Kristensen et al., 2003).

As a tropical legume, sunn hemp (Crotalaria juncea L.) is adapted to growth conditions found in the southeastern United States and Florida: sandy soils with low fertility characterized by a long warm season (Durairaj and Stute, 2018). Using sunn hemp as a rotational crop in organic strawberry production systems holds great potential for improving soil fertility and quality and environmental sustainability as this high-residue cover crop can help increase $\mathrm{SOM}$, contribute to $\mathrm{N}$ supply through $\mathrm{N}$-fixation, reduce weed pressure, and suppress sting nematodes (Belonolaimus longicaudatus), a major soilborne pest for strawberry production in Florida (Blanco-Canqui et al., 2012; Braz et al., 2016). As a green manure, sunn hemp can produce between 5000 and $11,500 \mathrm{~kg} \cdot \mathrm{ha}^{-1}$ dry weight of biomass with an estimated $\mathrm{N}$ input of 100 to $200 \mathrm{~kg} \cdot \mathrm{ha}^{-1} \mathrm{~N}$ (Ozores-Hampton, 2012; Schomberg et al., 2007). Although sunn hemp has been increasingly adopted as a summer cover crop by organic strawberry producers in Florida, there is limited information available on how much $\mathrm{N}$ sunn hemp residues provide to fall-planted strawberry crops. Considering the coarse texture of Florida's sandy soils, there is also a need for reliable methods to help predict and monitor the dynamics of plant-available N (PAN) released from cover crop residues.

AEMs have been used to measure plant available soil $\mathrm{NO}_{3}-\mathrm{N}$ dynamically in agricultural fields (Hill et al., 2016; Nyiraneza et al., 2009). AEMs are semipermeable membranes containing positively charged head groups attached to polymer resins. The head groups in AEMs enable the adsorption of anions while repelling cations. Quaternary ammonium head groups are the commonly used anion-conducting groups of AEMs due to their simple synthesis process (Hagesteijn et al., 2018). When buried into the soil for a given period, AEM resins act as an anion sink and are capable of continuously adsorbing anion forms of nutrients present in soils through ion exchange reactions in the head groups. Thus, resins mimic ion interception by roots, while the adsorption and accumulation of nutrient anions are driven by anion movement in response to concentration gradients in the soil solution (Yang et al., 1991). By contrast, it is challenging to employ traditional soil sampling and chemical extraction methods to quantify $\mathrm{NO}_{3}-\mathrm{N}$ availability and reveal in situ $\mathrm{N}$ release pattern due to the dynamic nature of the $\mathrm{N}$ cycle and the disadvantage of using inherently static measurements in this context (Abrams and Jarrel, 1992). AEMs can be viewed as a diffusionsensitive tool to monitor soil $\mathrm{N}$ availability because the process of nitrate accumulation on the resins integrates $\mathrm{N}$ transformations and $\mathrm{N}$ diffusion to sinks into the measurement of $\mathrm{N}$ availability (Qian and Schoenau, 
2002). It is also considered an innovative and practical in situ method that is cost-effective and simple to deploy (Qian and Schoenau, 2002; Skogley and Dobermann, 1996). A previous pot study demonstrated that AEM measurements could be used as a sensitive indicator of $\mathrm{NO}_{3}-\mathrm{N}$ dynamics in soils with green manure amendments (León Castro and Whalen, 2016).

In addition to in situ measurements, laboratory incubation methods have been employed to effectively estimate the $\mathrm{N}$ mineralization potential of soils amended with cover crop residues (Johnson et al., 2012; Masunga et al., 2016). To our knowledge, the potential of AEMs as a tool for monitoring in-situ soil $\mathrm{NO}_{3}-\mathrm{N}$ availability has not been examined in Florida sandy soils amended with organic inputs. Moreover, few studies have attempted to use multiple methods to determine the $\mathrm{N}$ release pattern of soils amended with sunn hemp residues. In addition to understanding soil $\mathrm{N}$ availability dynamics as affected by sunn hemp as a preceding cover crop in organic strawberry production systems, the impact of sunn hemp residues on strawberry yield performance also needs to be examined as little information is currently available.

The objectives of this 2-year study established on Florida sandy soils were to 1) monitor soil $\mathrm{NO}_{3}-\mathrm{N}$ fluxes using AEMs in an organic strawberry production field where sunn hemp cover crop residues were incorporated before strawberry planting; 2) determine site-specific $\mathrm{N}$ availability patterns of soils amended with sunn hemp residues using a combined approach including AEMs, traditional soil testing, and laboratory incubations; and 3) examine the influence of sunn hemp residues on organic strawberry fruit yield components in the early season.

\section{Materials and Methods}

Experimental setup and sunn hemp planting. This 2-year study was conducted on certified organic land at the University of Florida Plant Science Research and Education Unit (PSREU) in Citra, FL, in 2017 and 2018. The soil type at the research site is Gainesville loamy sand (hyperthermic coated typic quartzipsamments) with $96.8 \%$ sand, $2 \%$ clay, $1.2 \%$ silt, and a soil bulk density of $1.54 \mathrm{~g} \cdot \mathrm{cm}^{-3}$. In both years, a split plot design with four replications was used for field trials, with the sunn hemp treatment and the weedy fallow control as the whole plots arranged in

Received for publication 14 Aug. 2020. Accepted for publication 3 Nov. 2020.

Published online 30 December 2020.

This work is supported by the Organic Agriculture Research and Extension Initiative grant no. 2015-51300-24134 from the U.S. Department of Agriculture National Institute of Food and Agriculture.

X.Z. is the corresponding author. E-mail: zxin@ ufl.edu.

This is an open access article distributed under the $\mathrm{CC}$ BY-NC-ND license (https://creativecommons.org/ licenses/by-nc-nd/4.0/). a randomized complete block design. The subplot treatments differed between 2017 and 2018 trials. In 2017, the subplots consisted of four organic fertilization treatments, including no fertilizer control, preplant fertilization $\left(84.1 \mathrm{~kg} \cdot \mathrm{ha}^{-1} \mathrm{~N}\right)$, in-season fertigation $\left(328.7 \mathrm{~kg} \cdot \mathrm{ha}^{-1} \mathrm{~N}\right)$, and a combination of both preplant fertilization and in-season fertigation. In 2018, the nonfertilized control was not included and the preplant fertilization $\left(224 \mathrm{~kg} \cdot \mathrm{ha}^{-1} \mathrm{~N}\right)$ and in-season fertigation $\left(224 \mathrm{~kg} \cdot \mathrm{ha}^{-1} \mathrm{~N}\right)$ treatments were randomized in the subplots. Strawberry cultivar Sweet Sensation ${ }^{\circledR}$ 'Florida127' (Production Lareault Inc., Lavaltrie, Quebec, Canada) was planted in both years.

Untreated seeds of sunn hemp (cultivar not specified by the seed company; Hancock Seed \& Company, Dade City, FL) were inoculated with OMRI-listed Guard- ${ }^{\circledR}$ seed inoculant (Verdesian Life Sciences, Cary, $\mathrm{NC}$ ) at a rate of $7.5 \mathrm{~g}$ inoculant per $1 \mathrm{~kg}$ seed before seeding in both years. Sunn hemp was broadcast-seeded at a seeding rate of 44.9 $\mathrm{kg} \cdot \mathrm{ha}^{-1}$ on 19 July 2017 and 24 July 2018. The control plots without sunn hemp were kept as a weedy fallow during the sunn hemp growing season in both years. Each whole plot (sunn hemp or weedy fallow) was $12 \mathrm{~m}$ long and $9 \mathrm{~m}$ wide in each replication. At the end of the growing season, sunn hemp was terminated and aboveground biomass was chopped into $\approx 5$-cm-long pieces of residues using a flail chopper (model 5700; Hiniker Company, Mankato, MN) and then rototilled into the soil at a depth of $10 \mathrm{~cm}$ on 21 Sept. 2017 and 26 Sept. 2018, respectively. In 2017 , a second tillage at a soil depth of 10 $\mathrm{cm}$ was conducted on 28 Sept., but no additional tillage occurred in 2018. The weedy fallow control plots received the same tillage management on the same day as the sunn hemp plots. In both years, granular organic fertilizer $10 \mathrm{~N}-0.9 \mathrm{P}-6.6 \mathrm{~K}$ (Nature Safe, Irving, TX) was applied for preplant fertilization (except for the no fertilizer control in 2017), and liquid fish fertilizer $5 \mathrm{~N}-0.4 \mathrm{P}-$ $0.8 \mathrm{~K}$ (JH Biotech, Inc., Ventura, CA) in combination with $\mathrm{Big}-\mathrm{K}^{\mathrm{TM}} 0 \mathrm{~N}-0 \mathrm{P}-41.5 \mathrm{~K}$ sulfate of potash ( $\mathrm{JH}$ Biotech, Inc.) were used for in-season fertigation through drip irrigation lines for the strawberry production season. In 2017, false raised beds were formed first and then followed by granular organic fertilizer application on the bed top, and tillage was used to mix organic fertilizer with soil at a depth of $15 \mathrm{~cm}$ on 12 Oct. On the same day, the final raised beds were made and covered with $0.03 \mathrm{~mm}$ black TIF (totally impermeable film) plastic mulch (Intergro, Inc., Clearwater, FL) and a single drip tape (30.5 cm emitter spacing, $3.4 \mathrm{~L} \cdot \mathrm{h}^{-1} \cdot \mathrm{m}^{-1}$ flow rate; Jain Irrigation, Inc., Haines City, FL) was placed on the soil surface in the middle of each bed. In 2018, both the application of granular organic fertilizer and the formation of final raised beds with plastic mulch occurred on 3 Oct., in a similar way as in 2017. Each final raised bed was $12 \mathrm{~m}$ long (in each subplot), $88.9 \mathrm{~cm}$ wide, and $17.8 \mathrm{~cm}$ high in both years. After the formation of final raised beds, planting holes were made using a hole punch wheel (Kennco Manufacturing, Inc., Ruskin, FL) on 13 Oct. 2017 and 4 Oct. 2018, with a depth of $10 \mathrm{~cm}$ and a diameter of $5 \mathrm{~cm}$, in two rows for each bed. Containerized (tray) transplants of strawberry were planted on 13 Oct. 2017 and 4 Oct. 2018. In both years, the experimental unit (subplot) consisted of 40 strawberry plants spaced at 30.5 $\mathrm{cm}$ within two rows $(30.5 \mathrm{~cm}$ spacing between rows), planted in a staggered pattern in each bed, with bed centers spaced at $1.5 \mathrm{~m}$. The weekly in-season fertigation started on 18 Oct. 2017 and 8 Oct. 2018. Nonfertilized control plots received no fertilizer in 2017. Plants were irrigated for 30 to $45 \mathrm{~min}$ two or three times per day, depending on the plant growth stage, rainfall, and temperature in both years.

Sunn hemp biomass measurements. Before sunn hemp termination, two $0.25-\mathrm{m}^{2}$ quadrats were used to collect the aboveground plant biomass for each whole plot on 20 Sept. 2017 and 25 Sept. 2018. Weeds were minimal in the sunn hemp treatment, and only sunn hemp aboveground biomass was collected in sunn hemp plots, whereas the weed biomass was measured in weedy fallow plots. Specific measurements included plant height (only for sunn hemp), dry weight of aboveground biomass, carbon (C) and $\mathrm{N}$ concentrations, and $\mathrm{C}: \mathrm{N}$ ratio. In 2018, sunn hemp plants were separated into leaves and stems for measurements of biomass dry weight and $\mathrm{C}$ and $\mathrm{N}$ concentrations. Plant biomass was dried at $65{ }^{\circ} \mathrm{C}$ for $7 \mathrm{~d}$ to determine dry weight. Dried plant biomass was then ground through a $1-\mathrm{mm}$ sieve using a Wiley laboratory mill (Model 4; Thomas Scientific, Swedesboro, NJ), before $\mathrm{C}$ and $\mathrm{N}$ concentration analysis by dry combustion (by Waters Agricultural Laboratories, Inc., Camilla, GA).

Application of AEMs. AEMs (membrane type: AR204SZRA; SUEZ's Water Technologies \& Solutions, Trevose, PA) were used to measure in-situ $\mathrm{NO}_{3}-\mathrm{N}$ fluxes for both years. These AEMs consisted of cross-linked copolymers of vinyl monomers and quaternary ammonium anion-exchange groups and had a maximum anion exchange capacity of 2.4 meq. $\mathrm{g}^{-1}$ dry resin. Before the application in the field, AEM strips were prepared and charged with counterion by successively shaking on a platform shaker (Model classic C2; New Brunswick Scientific Co., Inc., Edison, $\mathrm{NJ}$ ) at $40 \mathrm{rpm}$ in $0.5 \mathrm{M} \mathrm{HCl}$ solution for $1 \mathrm{~h}$ first and then in $0.5 \mathrm{M} \mathrm{NaHCO}_{3}$ solution for $5 \mathrm{~h}$. When shaking AEM strips in the $\mathrm{NaHCO}_{3}$ solution, the solution was changed every hour to gradually saturate anion exchange sites with $\mathrm{HCO}_{3}^{-}$. $\mathrm{HCl}$ solution was used to provide $\mathrm{Cl}^{-}$as an intermediate counterion to increase the efficiency of saturating AEMs with $\mathrm{HCO}_{3}{ }^{-}$counterion (Qian and Schoenau, 1996). $\mathrm{HCO}_{3}^{-}$was used as the counterion because $\mathrm{HCO}_{3}^{-}$has much lower affinity to AEMs compared with the majority of soil nutrient anions including $\mathrm{NO}_{3}{ }^{-}$, whereas the $\mathrm{HCO}_{3}{ }^{-}$exchanged by the nutrient anions in the soil mimics the $\mathrm{HCO}_{3}{ }^{-}$produced through 
$\mathrm{CO}_{2}$ release from plant roots in the rhizosphere (Yang et al., 1991).

Two AEM strips $(10 \mathrm{~cm}$ deep $\times 2.5 \mathrm{~cm}$ wide each) were randomly buried in the top $10 \mathrm{~cm}$ of soil in each whole plot and replaced with new membranes weekly starting from sunn hemp incorporation (21 Sept. 2017 and 26 Sept. 2018) until the formation of raised beds with plastic mulch (12 Oct. 2017 and 3 Oct. 2018). After the formation of plastic mulched raised beds, two empty planting holes in each bed (subplot) were randomly picked and used for the placement of two AEM strips. The empty planting holes were used for AEM strips placement to avoid the interference from strawberry plant roots and rhizosphere microorganisms (Kuzyakov and $\mathrm{Xu}, 2013)$. In 2017, AEM strips were placed only in the sunn hemp and weedy fallow plots with the no fertilizer control. In 2018, AEMs were placed in all the sunn hemp and weedy fallow plots with preplant fertilization or inseason fertigation. AEM strips were inserted in planting holes and replaced biweekly from 13 Oct. to 5 Dec. in 2017 , and from 4 Oct. to 12 Dec. in 2018.

On each sampling event, AEM strips were removed from the field, washed repeatedly with distilled water to remove soil particles in the field, and stored in 50-mL screwcap centrifuge tubes (Thermo Fisher Scientific, Waltham, MA) with distilled water in a refrigerator $\left(4{ }^{\circ} \mathrm{C}\right)$ until desorption. AEM strips were eluted to desorb anions by adding $35 \mathrm{~mL}$ of $2 \mathrm{M} \mathrm{KCl}$ eluent to each tube and shaking on a platform shaker at $70 \mathrm{rpm}$ for 2 h. The elution solution was filtered through Fisherbrand Q2 filter paper (Thermo Fisher Scientific) and analyzed for $\mathrm{NO}_{3}-\mathrm{N}$ concentration using a continuous flow autoanalyzer (OI Analytical, College Station, TX) (Zhang, 2000). Soil $\mathrm{NO}_{3}-\mathrm{N}$ fluxes measured by AEM strips were expressed in micrograms per $\mathrm{cm}^{2}$ per day, based on the membrane area and the duration of AEM strip placement in the soil.

To verify the efficacy of using AEMs for adsorbing $\mathrm{NO}_{3}-\mathrm{N}$, a simple laboratory experiment was also conducted using solutions of different $\mathrm{NO}_{3}-\mathrm{N}$ concentrations $(0,20,50$, 100 , and $300 \mathrm{mg} / \mathrm{L}$ ), obtained by dissolving $\mathrm{NaNO}_{3}$ in deionized water. One AEM strip $(10 \times 2.5 \mathrm{~cm}$ each $)$ was inserted into each 50 $\mathrm{mL}$ screwcap centrifuge tube containing 50 $\mathrm{mL}$ of $\mathrm{NaNO}_{3}$ solution at a given concentration. Quadruplicates (four tubes) were used to determine $\mathrm{NO}_{3}-\mathrm{N}$ adsorbed on AEMs for each concentration after 1,2 , or 3 weeks. The procedure for preparation and desorption of AEM strips were the same as what was used for soils.

Soil sampling. To determine soil extractable $\mathrm{NO}_{3}-\mathrm{N}$ concentrations, soil samples were randomly taken at a depth of $15 \mathrm{~cm}$, using a 1.9-cm diameter soil probe (Oakfield Apparatus Company, Oakfield, WI) in both years. Eight cores were pooled per plot, using the same plots where AEMs were deployed. In 2017, soil samples were collected only from the sunn hemp and weedy fallow plots with the no fertilizer control. In 2018, soil samples were collected from all the sunn hemp and weedy fallow plots with the preplant fertilization or in-season fertigation treatment. Except for initial soil samples collected immediately following sunn hemp incorporation on 21 Sept. 2017 and 26 Sept. 2018, all other soil samplings occurred simultaneously with AEM strip replacement in both years. The $\mathrm{NO}_{3}-\mathrm{N}$ concentration for each soil sample was determined using flow injection analysis (by Waters Agricultural Laboratories, Inc., Camilla, GA).

Laboratory incubation study. The laboratory incubation study was only conducted for $\mathrm{N}$ mineralization of sunn hemp residues in 2018, collecting soils before fertilization. Soil samples $(0-10 \mathrm{~cm})$ were collected on 26 Sept. 2018, using a 1.9-cm diameter soil probe for each whole plot of sunn hemp or weedy fallow in the four replications, after sunn hemp residue soil incorporation. Eight soil cores were pooled per whole plot, resulting in eight composite soil samples (two treatments $\times$ four replications). On the basis of data from the Florida Automated Weather Network (FAWN) station for PSREU (Citra, FL), the average soil temperature at the 10$\mathrm{cm}$ depth without plastic mulch cover was $24{ }^{\circ} \mathrm{C}$ from late Sept. until Dec. 2017. This was selected as the incubation temperature. Soil moisture content was measured by oven drying $20 \mathrm{~g}$ of soil from each soil sample at $105^{\circ} \mathrm{C}$ for $24 \mathrm{~h}$. Before starting the laboratory incubation experiment, baseline $\mathrm{NO}_{3}-\mathrm{N}$ and $\mathrm{NH}_{4}-\mathrm{N}$ concentrations were measured by extracting $5 \mathrm{~g}$ of soil for each soil sample with $25 \mathrm{~mL}$ of $2 \mathrm{M} \mathrm{KCl}$ for $20 \mathrm{~min}$ at $280 \mathrm{osc} /$ min on a reciprocal shaker (Model E6010; Eberbach Corp., Belleville, MI). Duplicate extractions were performed for each soil sample. The extractions were centrifuged at $5000 \mathrm{rpm}$ for $5 \mathrm{~min}$ under ambient temperature $\left(22 \pm 2{ }^{\circ} \mathrm{C}\right)$ in an IEC centrifuge (FL40; Thermo Fisher Scientific), with the supernatant filtered through Fisherbrand Q2 filter paper.

Eight grams of fresh soil for each soil sample were placed into duplicate $120-\mathrm{mL}$ translucent specimen cups (Thermo Fisher Scientific) for this 8-week incubation study. Sixty-four cups (eight soil samples $\times$ two cups $\times$ four incubation times) were incubated at $24{ }^{\circ} \mathrm{C}$ in darkness in an incubator (Thermo Fisher Scientific) so that duplicate cups for each soil sample could be removed from the incubator at the end of each incubation time $(1,2,4$, and 8 weeks). All specimen cups were screwed loosely using thread caps to create aerobic condition. Soil moisture content was adjusted weekly by adding distilled water to each cup to maintain the original soil moisture level after checking the weight loss of each cup throughout the incubation period. Plant available $\mathrm{N}\left(\mathrm{NO}_{3}-\mathrm{N}\right.$ and $\left.\mathrm{NH}_{4}-\mathrm{N}\right)$ was quantified after 0 (baseline), 1, 2, 4, and 8 weeks to estimate the amount of $\mathrm{N}$ mineralized from the sunn hemp treatment and the weedy fallow control over time. PAN measurements were conducted by pulling out the duplicate cups of each soil sample from the incubator and extracting the $8 \mathrm{~g}$ of soil in each cup with $40 \mathrm{~mL}$ of $2 \mathrm{M} \mathrm{KCl}$ for $20 \mathrm{~min}$ on a reciprocal shaker. All cups were stored overnight to allow soil particles to settle and then filtered with Fisherbrand Q2 filter paper in the morning. The $\mathrm{NO}_{3}-\mathrm{N}$ and $\mathrm{NH}_{4}-\mathrm{N}$ concentrations in solution were determined for all cups by colorimetry (Doane and Horwáth, 2003; Weatherburn, 1967) using a microplate reader (Epoch 2; BioTek Instruments, Inc., Winooski, VT).

The following equations were established to conduct $\mathrm{N}$ mineralization calculations:

$$
\begin{aligned}
& \mathrm{N} \text { mineralized I }(\mathrm{mg} \mathrm{N} / \mathrm{kg} \text { soil }) \\
& =\left(\mathrm{NO}_{3}-\mathrm{N}+\mathrm{NH}_{4}-\mathrm{N}\right)_{\text {amended }} \\
& -\left(\mathrm{NO}_{3}-\mathrm{N}+\mathrm{NH}_{4}-\mathrm{N}\right)_{\text {control }}
\end{aligned}
$$

$$
\begin{aligned}
& \mathrm{N} \text { mineralized II }(\mathrm{mg} \mathrm{N} / \mathrm{kg} \text { soil }) \\
& =\left(\mathrm{NO}_{3}-\mathrm{N}+\mathrm{NH}_{4}-\mathrm{N}\right)_{\text {incubation }} \\
& -\left(\mathrm{NO}_{3}-\mathrm{N}+\mathrm{NH}_{4}-\mathrm{N}\right)_{\text {initial }}
\end{aligned}
$$

\section{Percent of $\mathrm{N}$ mineralized I}

$=\mathrm{N}$ mineralized $\mathrm{I} /$ Total $\mathrm{N}$ supplied $\times 100$

Percent of N mineralized II

$=\mathrm{N}$ mineralized II $/$ Total $\mathrm{N}$ supplied $\times 100$

$\mathrm{N}$ mineralization rate $(\mathrm{mg} \mathrm{N} / \mathrm{kg}$ soil $/ \mathrm{d})$

$=\mathrm{N}$ mineralized II / incubation period

where $\left(\mathrm{NO}_{3}-\mathrm{N}+\mathrm{NH}_{4}-\mathrm{N}\right)_{\text {amended }}$ is the total concentration of $\mathrm{NO}_{3}-\mathrm{N}$ and $\mathrm{NH}_{4}-\mathrm{N}$ in the soil amended with sunn hemp at the end of the 8-week incubation period; $\left(\mathrm{NO}_{3}-\mathrm{N}+\mathrm{NH}_{4}\right.$ $-\mathrm{N})_{\text {control }}$ is the total concentration of $\mathrm{NO}_{3}-\mathrm{N}$ and $\mathrm{NH}_{4}-\mathrm{N}$ in the soil from the weedy fallow at the end of the 8-week incubation period; $\left(\mathrm{NO}_{3}-\mathrm{N}+\mathrm{NH}_{4}-\mathrm{N}\right)_{\text {incubation }}$ is the total concentration of soil $\mathrm{NO}_{3}-\mathrm{N}$ and $\mathrm{NH}_{4}-\mathrm{N}$ at the end of a certain incubation period $(1,2,4$, or 8 weeks); $\left(\mathrm{NO}_{3}-\mathrm{N}+\mathrm{NH}_{4}-\mathrm{N}\right)_{\text {initial }}$ is the total concentration of soil $\mathrm{NO}_{3}-\mathrm{N}$ and $\mathrm{NH}_{4}-\mathrm{N}$ at the beginning of a certain incubation period; and total $\mathrm{N}$ supplied is the total amount of $\mathrm{N}$ accumulated in the aboveground sunn hemp biomass (Azeez and Van Averbeke, 2010; Zare and Ronaghi, 2019).

Two methods were used to estimate the amount of $\mathrm{N}$ mineralized from sunn hemp residues. Eq. [1] calculated sunn hemp $\mathrm{N}$ mineralization using the difference in PAN between sunn hemp amended and weedy fallow control soils at the end of the 8-week incubation period (Mohanty et al., 2011), and Eq. [2] calculated the difference in PAN between the end of the 8-week incubation period and the baseline (week 0) for sunn hemp amended soils (Zare and Ronaghi, 2019). Accordingly, percent of $\mathrm{N}$ mineralized from the total amount of $\mathrm{N}$ accumulated in the aboveground sunn hemp biomass was 
Table 1. Aboveground biomass and tissue $\mathrm{C}$ and $\mathrm{N}$ analysis of sunn hemp at termination and soil incorporation in comparison with weedy fallow in the 2017 and 2018 trials in Citra, FL.

\begin{tabular}{lcrrr}
\hline Cover crop $^{z}$ & Aboveground dry biomass $^{\mathrm{y}}\left(\mathrm{kg} \cdot \mathrm{ha}^{-1}\right)$ & $\mathrm{N}$ concn $\left(\mathrm{g} \cdot \mathrm{kg}^{-1}\right)$ & $\mathrm{C}$ concn $\left(\mathrm{g} \cdot \mathrm{kg}^{-1}\right)$ & $\mathrm{N}$ accumulation $\left(\mathrm{kg} \cdot \mathrm{ha}{ }^{-1}\right)$ \\
\hline & & & 2017 & $\mathrm{C}: \mathrm{N}$ \\
Sunn hemp & $6806 \pm 391 \mathrm{a}$ & $23.0 \pm 2.1 \mathrm{a}$ & $475.1 \pm 2.8 \mathrm{a}$ & $156.5 \pm 10.1 \mathrm{a}$ \\
Weedy fallow & $2837 \pm 131 \mathrm{~b}$ & $15.6 \pm 1.8 \mathrm{~b}$ & $353.0 \pm 34.1 \mathrm{~b}$ & $44.0 \pm 5.6 \mathrm{~b}$ \\
& & & 2018 & $23: 1 \pm 2: 1 \mathrm{a}$ \\
Sunn hemp leaves & $1808 \pm 48 \mathrm{c}$ & $42.3 \pm 1.7 \mathrm{a}$ & $419.2 \pm 2.3 \mathrm{c}$ & $76.5 \pm 3.7 \mathrm{~b}$ \\
Sunn hmp stems & $3347 \pm 301 \mathrm{~b}$ & $13.8 \pm 0.5 \mathrm{~d}$ & $433.0 \pm 0.5 \mathrm{a}$ & $10: 1 \pm 0: 1 \mathrm{c}$ \\
Sunn hemp & $5155 \pm 343 \mathrm{a}$ & $23.8 \pm 0.7 \mathrm{~b}$ & $428.1 \pm 0.9 \mathrm{~b}$ & $122.6 \pm 8.5 \mathrm{c}$ \\
Weedy fallow & $2365 \pm 803 \mathrm{c}$ & $19.6 \pm 4.3 \mathrm{c}$ & $289.7 \pm 28.0 \mathrm{~d}$ & $32: 1 \pm 1: 1 \mathrm{a}$ \\
\hline
\end{tabular}

${ }^{\mathrm{z}}$ Sunn hemp was broadcast seeded on 19 July 2017 and 24 July 2018 and aboveground biomass was flail-chopped and incorporated into the soil on 21 Sept. 2017 and 26 Sept. 2018 . Weedy fallow plots were tilled on the same day when sunn hemp was incorporated. Sunn hemp plant height at termination was $\approx 1.60 \mathrm{~m}$ in 2017 and $\approx 1.58 \mathrm{~m}$ in 2018 .

${ }^{\mathrm{y}}$ Weed biomass was measured in weedy fallow plots. Weeds were minimal and no measurements for weed biomass were taken in sunn hemp plots.

${ }^{\mathrm{x}}$ Aboveground dry biomass of sunn hemp $=$ leaf biomass + stem biomass. $\mathrm{N}$ or $\mathrm{C}$ concentration of sunn hemp $=(\mathrm{N}$ or $\mathrm{C}$ concentration of sunn hemp leaves $\times$ dry biomass of leaves $+\mathrm{N}$ or $\mathrm{C}$ concentration of sunn hemp stems $\times$ dry biomass of stems) / (dry biomass of sunn hemp leaves + dry biomass of sunn hemp stems). Data are presented as mean \pm standard deviation $(n=4)$.

Means within a column followed by the same letters for a given year are not significantly different by Fisher's least significant difference test at $P \leq 0.05$.

calculated by Eqs. [3] and [4], respectively. The amount of $\mathrm{N}$ mineralized from the weedy fallow control sample was calculated by Eq. [2]. As indicated by Eq. [5], the N mineralization rate of sunn hemp during a given incubation period ( 0 to 2 weeks, 2 to 4 weeks, and 4 to 8 weeks) was calculated by dividing the amount of $\mathrm{N}$ mineralized in Eq. [2] by the incubation period (days).

Organic strawberry early-season yield evaluation. Strawberry harvests started on 4 Dec. 2017 and 26 Nov. 2018 and ended on 1 May 2018 and 25 Apr. 2019, respectively. Ripe fruit were harvested twice a week from 40 strawberry plants in each subplot and classified into marketable and unmarketable (small and deformed, diseased, and pest damaged fruit) categories following the U.S. Department of Agriculture standards for grades of strawberries (USDA-AMS, 2006). The classified fruits were measured to record fruit number and fresh weight for marketable and unmarketable yield components, and data were reported on a per-plant basis. The average fruit weight was determined by dividing marketable fruit fresh weight yield by marketable fruit number. This article focuses only on early-season yield components from both years (December harvests in 2017 and November to December harvests in 2018), comparing sunn hemp and weedy fallow plots at a time when soil $\mathrm{NO}_{3}-\mathrm{N}$ fluxes and extractable $\mathrm{NO}_{3}-\mathrm{N}$ concentrations were monitored.

Statistical analyses. Data were analyzed using a linear mixed model with the GLIMMIX procedure in SAS (version 9.4; SAS Institute, Cary, NC). All data were checked for normality, homogeneity of variance, and linearity to determine if data transformations were necessary. In 2017, sunn hemp biomass, soil $\mathrm{NO}_{3}-\mathrm{N}$ fluxes monitored by AEMs, soil $\mathrm{NO}_{3}-\mathrm{N}$ concentrations measured by traditional soil testing, and early season fruit yield components were analyzed from the sunn hemp and weedy fallow plots with no fertilizer. In 2018, data were analyzed for the sunn hemp and weedy fallow plots in combination with the two fertilization treatments. Thus, a one-way analysis of variance (ANOVA; cover crop factor) was performed in 2017, and a two-way ANOVA (cover crop and fertilization factors in addition to their interaction) was conducted in 2018. For soil $\mathrm{NO}_{3}-\mathrm{N}$ and $\mathrm{NH}_{4}-\mathrm{N}$ concentrations measured in the incubation study, only the cover crop factor was considered in data analysis. Fisher's least significant difference test was used for multiple comparisons among different treatments at $P \leq 0.05$.

Data analyses of the AEM experiment in the pure solution system were performed in $\mathrm{R}$ (version 4.0; R Core Team, 2020). Analysis of covariance (ANCOVA) was used to estimate the parameters (slopes and intercepts) of regression lines for predicting the amount of $\mathrm{NO}_{3}-\mathrm{N}$ adsorbed on AEMs in response to $\mathrm{NO}_{3}-\mathrm{N}$ concentrations in the pure solution system over different incubation periods $(1$, 2 , and 3 weeks). A likelihood-ratio test ( $\alpha=$ 0.05 ) was then performed to compare the slopes and intercepts of regression lines to determine whether incubation time had a significant effect on the amount of $\mathrm{NO}_{3}-\mathrm{N}$ adsorbed on AEMs deployed in solutions with different nitrate concentrations (Kim and Siegmund, 1989).

\section{Results and Discussion}

Sunn hemp biomass assessment. In both years, sunn hemp accumulated significantly greater amounts of $\mathrm{N}$ (by $180 \%$ to $256 \%$ ) and aboveground biomass (by $118 \%$ to $140 \%$ ), with higher $\mathrm{N}$ concentrations compared with the weed biomass in weedy fallow plots (Table 1). Despite similar plant height between the two years, sunn hemp aboveground biomass at termination was $32 \%$ greater in 2017 than in 2018. N concentration of sunn hemp residues was similar in both years, but tissue $\mathrm{C}$ concentration was $11 \%$ higher in 2017 than in 2018, resulting in a higher C:N ratio in 2017 than in 2018. Sunn hemp aboveground biomass and $\mathrm{N}$ accumulation reported here fall within the range of 4000 to $8000 \mathrm{~kg} \cdot \mathrm{ha}^{-1}$ dry weight and 100 to 200 $\mathrm{kg} \cdot \mathrm{ha}^{-1} \mathrm{~N}$ measured at $60 \mathrm{~d}$ after seeding by Schomberg et al. (2007). The difference we observed between the 2 years could be attributed to distinct weather conditions (Cherr et al., 2006). During the sunn hemp growing period (19 July to 21 Sept. in 2017; 24 July to 26 Sept. in 2018), total rainfall was $582 \mathrm{~mm}$ in 2017 and $273 \mathrm{~mm}$ in 2018, whereas average daily air temperature was $26.8^{\circ} \mathrm{C}$ in 2017 and $27.0^{\circ} \mathrm{C}$ in 2018 .

In the weedy fallow plots, the amount of weed biomass at sunn hemp termination was 20\% greater in 2017 than in 2018 (Table 1). Crabgrass (Digitaria spp.) and yellow nutsedge (Cyperus esculentus L.) were the dominant weeds in 2017, whereas Florida pusley (Richardia scabra L.) was most abundant in 2018. The difference in dominant weed species may have accounted for the large difference in $\mathrm{C}: \mathrm{N}$ ratios of weed biomass observed between the two years, because grass species tend to have a higher $\mathrm{C}: \mathrm{N}$ ratio than broadleaf weed species (Lindsey et al., 2013).

In 2018, we compared the $\mathrm{C}: \mathrm{N}$ ratio of sunn hemp stem and leaf biomass analyzed separately and found that it was higher in stem relative to leaf tissues by 2.2 -fold, due to much higher $\mathrm{N}$ concentration in the leaves (Table 1). This finding is in line with Mansoer et al. (1997), who reported C:N ratios of sunn hemp leaves and stems ranging from 9:1 to 11:1 and from 29:1 to 40:1, respectively, after a 9-week growing period.

AEMs in the pure solution system. In the pure solution system, $\mathrm{NO}_{3}-\mathrm{N}$ adsorbed on AEMs increased linearly with increasing $\mathrm{NO}_{3}-\mathrm{N}$ concentration in solution during contact periods ranging from 1 to 3 weeks (Fig. 1). The relationship between $\mathrm{NO}_{3}-\mathrm{N}$ adsorbed on AEMs and $\mathrm{NO}_{3}-\mathrm{N}$ concentration of the solution was strong $\left(R^{2} \geq 0.98\right)$, confirming the ability of AEMs to detect different levels of $\mathrm{NO}_{3}-\mathrm{N}$ present in solutions of varying nitrate concentration. Based on ANCOVA results, there was no significant difference between the three regression lines corresponding to different contact periods $(P=0.2)$, suggesting that an incubation time varying between one and three weeks did not significantly affect the amount of $\mathrm{NO}_{3}-\mathrm{N}$ adsorbed on AEMs in the static pure solution system. When applying AEMs in the soil system, however, burial times longer than 2 weeks are not recommended because of highly variable soil temperature and moisture levels, biofilm growth on membranes, and the possible saturation of 


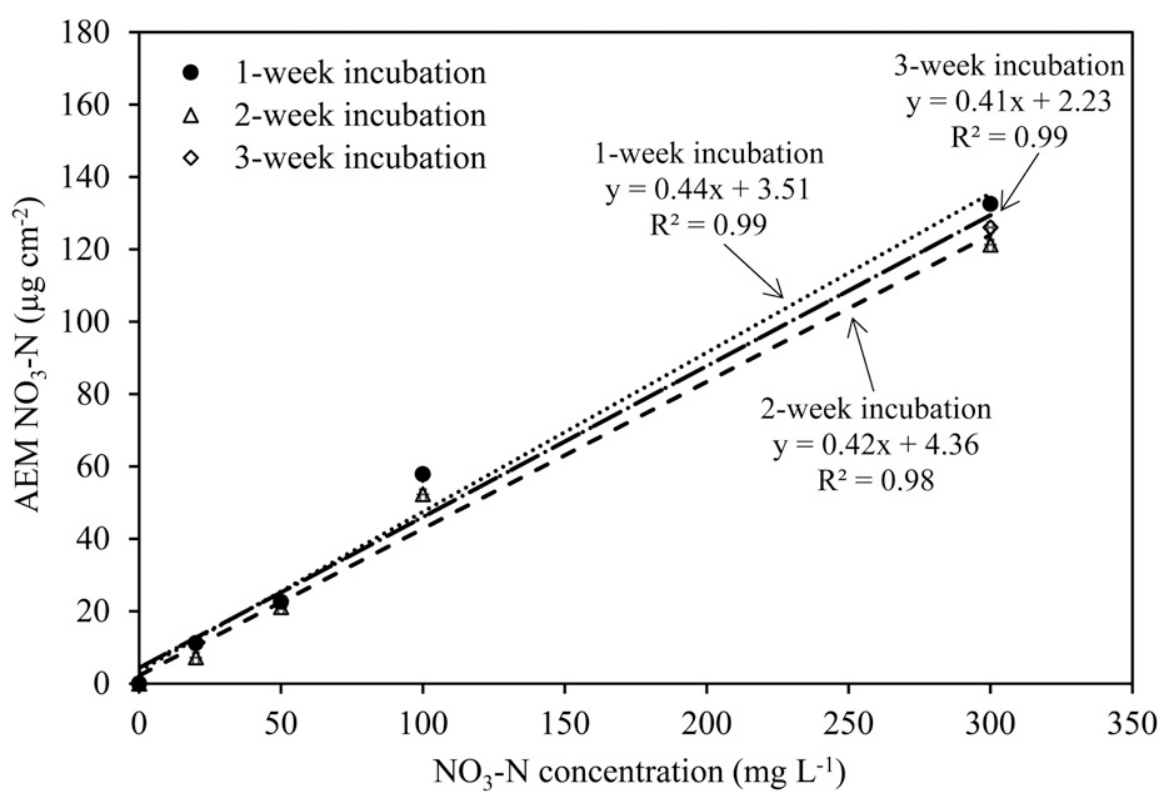

Fig. 1. $\mathrm{NO}_{3}-\mathrm{N}$ adsorbed on anion exchange membranes (AEMs) as a function of $\mathrm{NO}_{3}-\mathrm{N}$ concentration in the nitrate $\left(\mathrm{NaNO}_{3}\right)$ solutions during 1,2, and 3 weeks of incubation in the laboratory assays. There was no significant difference among the three regression lines $(P=0.2)$ according to analysis of covariance and likelihood-ratio tests $(\alpha=0.05)$.
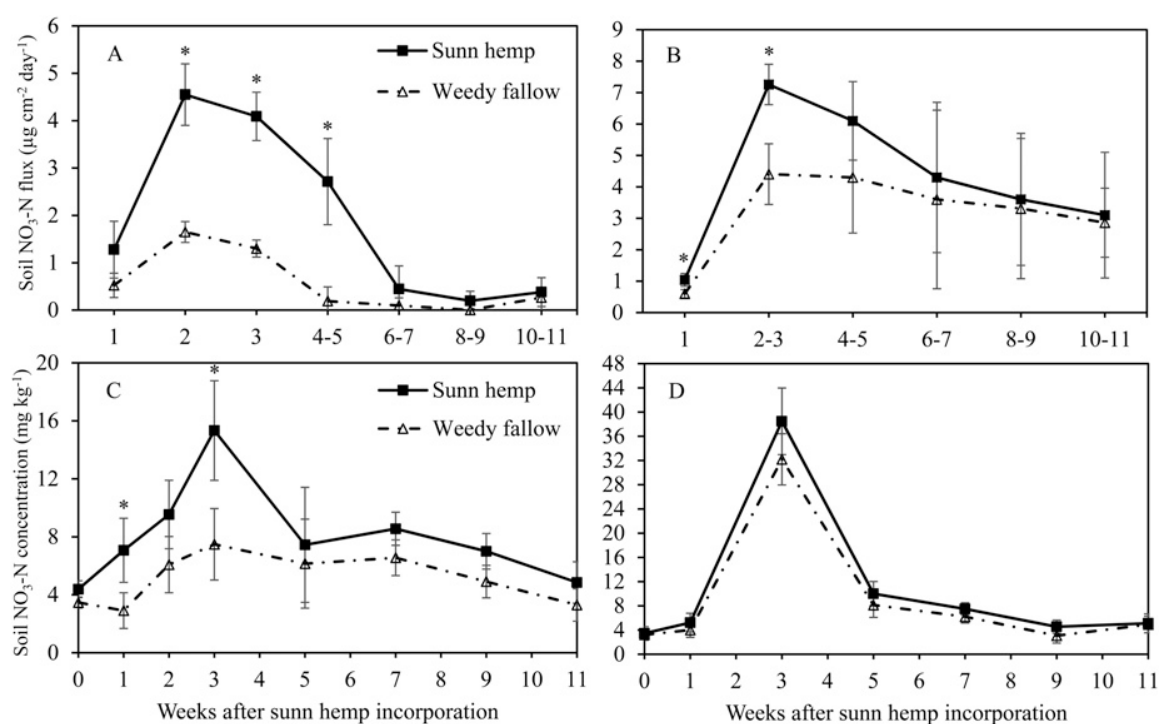

Fig. 2. Soil nitrate flux measured by anion exchange membranes in 2017 (A) and 2018 (B) and soil $\mathrm{NO}_{3}-\mathrm{N}$ concentration measured through traditional soil testing in 2017 (C) and 2018 (D) in sunn hemp and weedy fallow plots following biomass incorporation in Citra, FL. Error bars represent standard deviations $(n=4)$. Asterisks indicate a significant difference between sunn hemp and weedy fallow plots for a given time period according to Fisher's least significant difference test at $P \leq 0.05$. Sunn hemp residues were incorporated into the soil (weedy fallow plots tilled) on 21 Sept. 2017 and 26 Sept. 2018 (week 0). Strawberries were transplanted on 13 Oct. 2017 and 4 Oct. 2018.

membranes (Qian and Schoenau, 2002). Therefore, AEMs were buried in the soil for 1 or 2 weeks in the field study to take into consideration the $\mathrm{NO}_{3}-\mathrm{N}$ adsorption capacity of membranes and the resources required for sampling and processing (e.g., time, management, and cost).

Dynamics of $\mathrm{NO}_{3}-\mathrm{N}$ availability in the soil. In both years, $\mathrm{NO}_{3}-\mathrm{N}$ fluxes monitored by AEMs and $\mathrm{NO}_{3}-\mathrm{N}$ concentrations measured by traditional soil testing showed similar patterns of soil $\mathrm{NO}_{3}-\mathrm{N}$ availability after occurring in the first two WAI. Similar to Ziadi et al. (2006), we found significantly higher $\mathrm{NO}_{3}-\mathrm{N}$ fluxes monitored by AEMs after sunn hemp incorporation in comparison with the weedy fallow control, demonstrating the ability of AEMs to detect differences between soil amendment treatments and predict soil $\mathrm{NO}_{3}-\mathrm{N}$ availability.

In 2017, the traditional soil testing method detected a significantly higher concentration of $\mathrm{NO}_{3}-\mathrm{N}$ in the sunn hemp treatment relative to the weedy fallow control (by 143\%) at 1 WAI, whereas the $\mathrm{NO}_{3}-\mathrm{N}$ flux monitored by AEMs during the first week following sunn hemp residue incorporation did not show a significant difference $(P=0.07)$ (Fig. $2 \mathrm{~A}$ and $C)$. This could be explained by the reduced contact between AEM strips and nitrate anions in the soil solution given the limited rainfall and dry soil conditions (Qian and Schoenau, 1996) occurring during the AEM placement period in the 2017 season (Fig. 3). On the other hand, the $P$ value of 0.07 suggests an increasing trend for $\mathrm{NO}_{3}-\mathrm{N}$ fluxes after sunn hemp incorporation. The experimental plots were tilled at $1 \mathrm{WAI}$, and this could account for the rapid increase in $\mathrm{NO}_{3}-\mathrm{N}$ fluxes during the second week after sunn hemp incorporation because soil tillage may help enhance the decomposition of plant residues and $\mathrm{N}$ release. León Castro and Whalen (2019) found that increased tillage intensity enhanced $\mathrm{NO}_{3}-\mathrm{N}$ fluxes monitored by AEMs by reducing the size of green manure residues and by stimulating nitrification. Meanwhile, soil tillage could substantially increase $\mathrm{N}$ losses, especially when precipitation events occur shortly after tillage.

In 2018, lower C: $\mathrm{N}$ ratios in sunn hemp and weeds relative to 2017 were expected to result in a higher $\mathrm{N}$ mineralization potential, but soil $\mathrm{NO}_{3}-\mathrm{N}$ fluxes and concentrations measured in 2018 at 1 WAI were similar to those measured in 2017 (Fig. 2). This could be ascribed to two potential factors: lower aboveground biomass and $\mathrm{N}$ accumulation in sunn hemp and weeds for 2018 relative to 2017, and higher precipitation in 2018 $(17.5 \mathrm{~mm})$ relative to $2017(0 \mathrm{~mm})$ that likely increased $\mathrm{NO}_{3}-\mathrm{N}$ leaching potential in these sandy soils without plastic mulch cover (Jabloun et al., 2015). In contrast to 2017, AEMs seemed more sensitive than the traditional soil testing method to detect differences in soil $\mathrm{N}$ dynamics between the sunn hemp treatment and the weedy fallow control in 2018: soil $\mathrm{NO}_{3}-\mathrm{N}$ fluxes were significantly higher in the sunn hemp plots, but soil $\mathrm{NO}_{3}-\mathrm{N}$ concentrations were similar between the sunn hemp and weedy fallow plots during 1-3 WAI (Fig. 2B and D). Given the mobility of $\mathrm{NO}_{3}-\mathrm{N}$ in coarse-textured soils and the influence of rainfall and soil water on nitrate leaching, AEMs may be a more reliable tool than static soil sampling to monitor dynamics of soil $\mathrm{NO}_{3}-\mathrm{N}$ availability following cover crop termination and incorporation under Florida sandy soil conditions, consistent with previous work (León Castro and Whalen, 2019). 


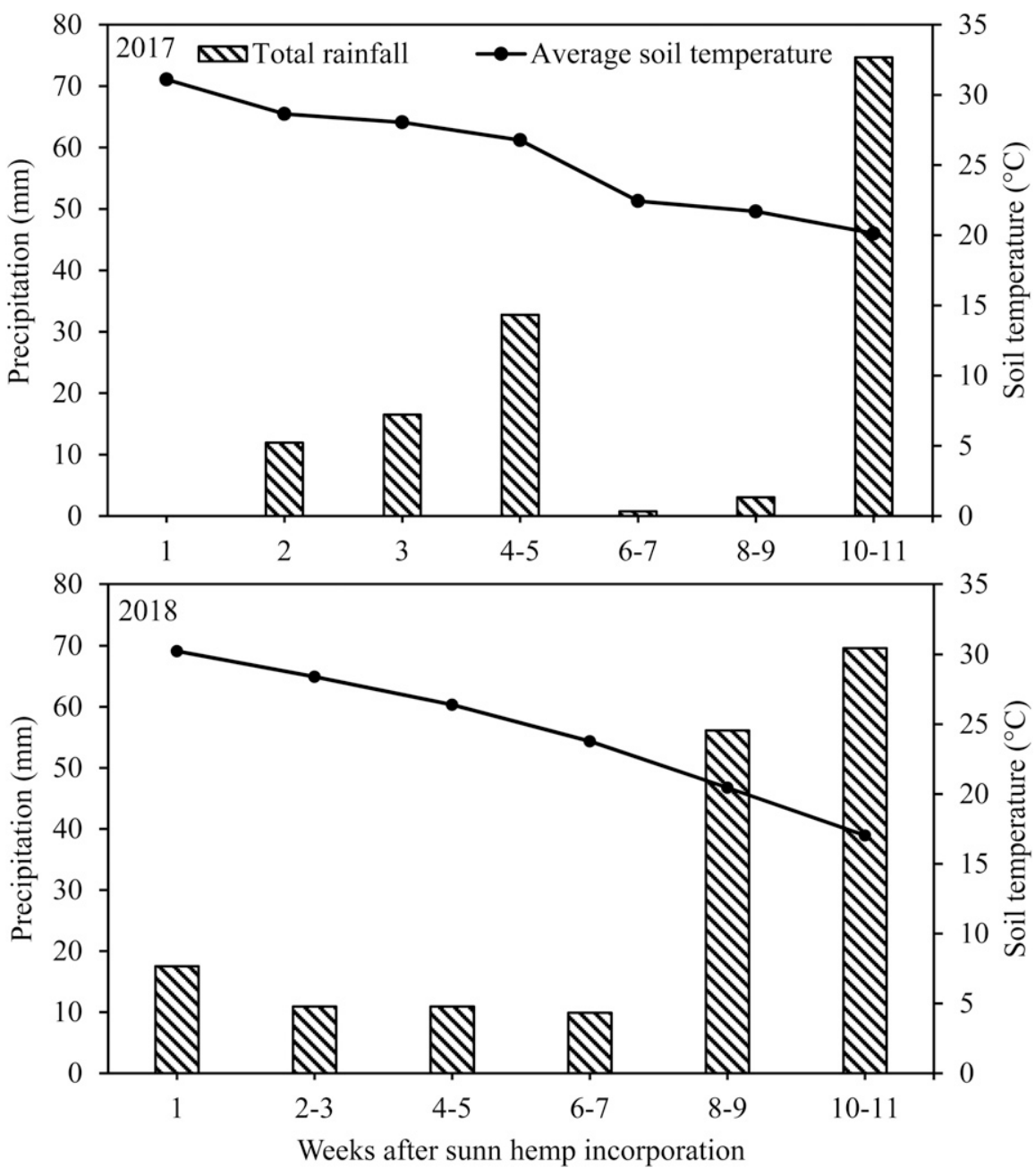

Fig. 3. Average soil temperature (10-cm soil depth, without plastic mulch cover) and total rainfall for the duration of anion exchange membrane (AEM) placement in the field in 2017 and 2018, after sunn hemp incorporation in Citra, FL. Data reported were from 21 Sept. to 6 Dec. in 2017 and 26 Sept. to 10 Dec. in 2018. Data Source: Florida Automated Weather Network (FAWN: https://fawn.ifas.ufl.edu).

In the plots amended with sunn hemp residues, peak values of soil $\mathrm{NO}_{3}-\mathrm{N}$ fluxes and concentrations reached $7.3 \mu \mathrm{g} \cdot \mathrm{cm}^{-2} \cdot \mathrm{d}^{-1}$ and $38.5 \mathrm{mg} \cdot \mathrm{kg}^{-1}$ in 2018 , respectively, which were higher than values observed in the 2017 season $\left(4.6 \mu \mathrm{g} \cdot \mathrm{cm}^{-2} \cdot \mathrm{d}^{-1}\right.$ and 15.3 $\mathrm{mg} \cdot \mathrm{kg}^{-1}$, respectively) (Fig. 2). In general, soil $\mathrm{NO}_{3}-\mathrm{N}$ fluxes and concentrations after 1 WAI were also higher in 2018 than in 2017. Although sunn hemp accumulated less aboveground biomass and $\mathrm{N}$ in 2018, the organic fertilizers applied to strawberry plants in both sunn hemp and weedy fallow plots (no fertilizer control plots were included in 2017 but not 2018) as well as the relatively low C:N ratio of sunn hemp residues in 2018 likely favored $\mathrm{N}$ mineralization, resulting in greater $\mathrm{N}$ availability. In addition to the total $\mathrm{C}$ and $\mathrm{N}$ concentrations of plant tissue, lignin: $\mathrm{N}$ and polyphenol:N ratios have been shown to significantly correlate with net $\mathrm{N}$ mineralization of crop residues (Kumar and Goh, 2003). Determining whether the biochemical composition of sunn hemp residues varies at different growing stages and under contrasting seasonal and environmental conditions, as well as how this variation affects $\mathrm{N}$ re- rapidly lost within 4 weeks after termination, in a reduced-tillage system under Florida sandy soil conditions.

$N$ mineralization study. Soil $\mathrm{NO}_{3}-\mathrm{N}$ increased through time during the laboratory incubation for both the sunn hemp treatment and the weedy fallow control, although soil amended with sunn hemp crop residues exhibited a significantly larger increase in soil $\mathrm{NO}_{3}-\mathrm{N}$ from 2 to 8 weeks of incubation (Fig. 4A). This was expected considering the significantly higher amount of $\mathrm{N}$ accumulated in sunn hemp aboveground biomass compared with the weedy fallow plots. In contrast, soil $\mathrm{NH}_{4}-\mathrm{N}$ concentrations showed a decreasing trend during the 8-week incubation, regardless of treatment (Fig. 4B). This reduction in soil $\mathrm{NH}_{4}-\mathrm{N}$ and concomitant increase in soil $\mathrm{NO}_{3}-\mathrm{N}$ over time was likely due to nitrification, driven by aerobic incubation conditions, and is consistent with $\mathrm{NO}_{3}-\mathrm{N}$ being the dominant form of PAN in soils under aerobic conditions (Maathuis, 2009).

In our study, the percent of mineralized $\mathrm{N}$ from sunn hemp after the 8-week incubation might be underestimated by using weedy fallow as the control in Eqs. [1] and [3] because the weedy fallow had an important amount of PAN returned to the soil through weed biomass. On the other hand, Eqs. [2] and [4] could overestimate $\mathrm{N}$ mineralization potential of sunn hemp because the $\mathrm{N}$ mineralization of soil organic matter likely contributed some amount of PAN. Thus, we decided to use these two methods to estimate the range of $\mathrm{N}$ mineralization potential of sunn hemp residues in the present study. Overall, by the end of the 8 -week laboratory incubation period, between $25.1 \%$ (when using Eqs. [1] and [3]) and 32.7\% (when using Eqs. [2] and [4]) of the $\mathrm{N}$ accumulated in sunn hemp biomass was released, which was equivalent to a PAN release between $30.8 \mathrm{~kg} \cdot \mathrm{ha}^{-1}$ (when using Eq. [1]) and 40.0 $\mathrm{kg} \cdot \mathrm{ha}^{-1}$ (when using Eq. [2]). These results are slightly lower than previous field-based $\mathrm{N}$ mineralization estimates obtained with the litterbag approach in Alabama, where 60day-old sunn hemp planted in July released $33.5 \%$ to $38.5 \%$ of total $\mathrm{N}$ accumulated in sunn hemp biomass by the end of a 60-day mineralization field trial (Stallings et al., 2017). The lower release estimates we obtained could be driven by laboratory conditions that exclude the activity of soil fauna and precipitation events.

As indicated by the steep slope displayed in Fig. 4A during the first 2 weeks of the incubation study, the net $\mathrm{N}$ mineralization rate peaked $(0.93 \mathrm{mg} \mathrm{N} / \mathrm{kg}$ soil $/ \mathrm{d}) 2$ weeks after the start of the incubation, in line with previous findings (Baitsaid et al., 2018; Stallings et al., 2017). The net $\mathrm{N}$ mineralization rate was dramatically reduced to 0.43 and $0.25 \mathrm{mg} \cdot \mathrm{kg}^{-1} \cdot \mathrm{d}^{-1}$ between 2 and 4 weeks and between 4 to 8 weeks after the start of the incubation, respectively. This rapid $\mathrm{N}$ release observed during mineralization is likely explained by the greater contribution of leaf tissue $(62 \%)$ over stems $(38 \%)$ in terms of 

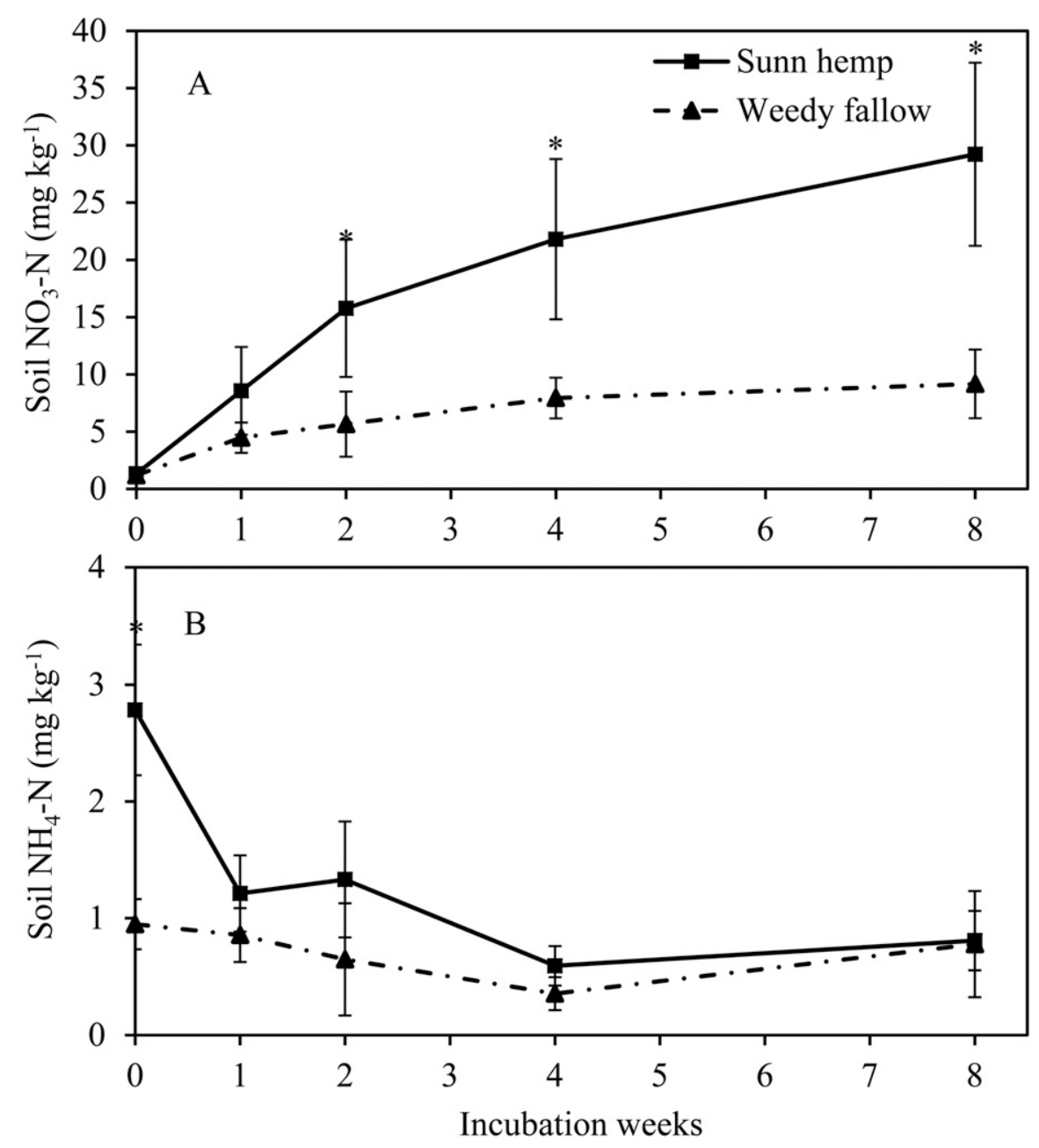

Fig. 4. Soil $\mathrm{NO}_{3}-\mathrm{N}(\mathbf{A})$ and $\mathrm{NH}_{4}-\mathrm{N}$ (B) concentrations determined by colorimetry during an 8-week incubation study conducted in the laboratory. Error bars represent standard deviations $(n=4)$. Asterisks indicate a significant difference between the sunn hemp treatment and the weedy fallow control according to Fisher's least significant difference test at $P \leq 0.05$.

biomass $\mathrm{N}$. These results are in agreement with previous reports that labile portions of sunn hemp (leaves and flowers) containing the majority of $\mathrm{N}$ decompose rapidly at first, leaving behind recalcitrant tissues (stems) that are resistant to decomposition due to low $\mathrm{N}$ concentration and high levels of complex carbon structures (e.g., lignin), resulting in lower $\mathrm{N}$ release rates at later stages of $\mathrm{N}$ mineralization (Mulvaney et al., 2010). Slower N release observed over time in the laboratory incubation also parallels the declining trend of soil $\mathrm{NO}_{3}-\mathrm{N}$ fluxes and concentrations observed after $3 \mathrm{WAI}$ in field trials for both years.

Results from all methods used in this study (8-week incubation, AEMs, traditional soil testing) indicate that sunn hemp residues decomposed and released $\mathrm{N}$ rapidly, with a rise in $\mathrm{N}$ availability within the first 2 to 3 weeks after sunn hemp incorporation. This fast release of available $\mathrm{N}$ from sunn hemp residues is likely asynchronous with crop demand because newly planted organic strawberry crops (transplanted at 22 and $8 \mathrm{~d}$ after sunn hemp incorporation in 2017 and 2018, respectively) are still experiencing the trol (Fig. 5A). Marketable fruit number per plant was also significantly higher in the sunn hemp plot by $46 \%$, and there was a trend $(P=$ 0.09 ) of higher total fruit number per plant (by $36 \%$ ) with sunn hemp relative to weedy fallow plots (Fig. 5B). On the basis of soil N availability findings from the 2017 trial, we reduced the waiting period between sunn hemp residue soil incorporation and strawberry transplanting from $22 \mathrm{~d}$ in 2017 to $8 \mathrm{~d}$ in 2018. The positive impact of sunn hemp on early-season fruit yield improvement was also detected in the 2018 trial, with significant increases in total fruit number (by $15 \%$ ) and weight yield (by 14\%) and marketable fruit number (by 13\%), in contrast to the weedy fallow control. In addition, marketable fruit weight yield tended to be higher in the sunn hemp treatment $(P=0.06)$. In both years, we did not find any significant sunn hemp effects on whole-season fruit yields (data not shown). Despite the increased potential for nitrate leaching during the first 3 to 4 weeks after sunn hemp residue incorporation, the elevated level of available $\mathrm{N}$ supply from sunn hemp might have benefited the early establishment of organic strawberry plants in the field, helping meet crop nutrient needs and promote early fruit production. However, strawberry plant $\mathrm{N}$ uptake and utilization need to be further examined to better understand the extent of this benefit. As reported in other studies, the contribution of sunn hemp residues to the subsequent cash crop yield performance in addition to the recovery of $\mathrm{N}$ from sunn hemp largely depend on the timing of $\mathrm{N}$ release from sunn hemp residues and the growth and nutrient uptake patterns of the subsequent cash crop (Elsaid and Silva, 2017; White et al., 2020). This deserves more research to show how sunn hemp residues as a $\mathrm{N}$ source can be effectively and efficiently integrated into organic nutrient management for strawberry production.

In this study, we used a flail chopper to terminate and mow the sunn hemp aboveground tissue into relatively small pieces $(5$ $\mathrm{cm}$ long), creating favorable conditions for decomposition and mineralization of sunn hemp residues. To improve the available $\mathrm{N}$ supply from sunn hemp to the subsequent crop and minimize nitrate leaching, different equipment or methods could be used to terminate sunn hemp and slow down the rate of decomposition and mineralization by manipulating the size of sunn hemp residues, although tillage may still be required for bed preparation to accommodate the following crop. On the other hand, it would be interesting to examine soil $\mathrm{N}$ dynamics in reduced tillage or no-till systems for strawberry planting. In addition, extending the sunn hemp growing period could increase the $\mathrm{C}: \mathrm{N}$ ratio of residues without causing severe $\mathrm{N}$ immobilization issues, if implements can handle the more fibrous plant tissues. Sunn hemp may also be grown with other cover crop(s) in polyculture to help balance $\mathrm{C}: \mathrm{N}$ ratios and $\mathrm{N}$ release. In the case of strawberry production, the delay between sunn hemp termination 

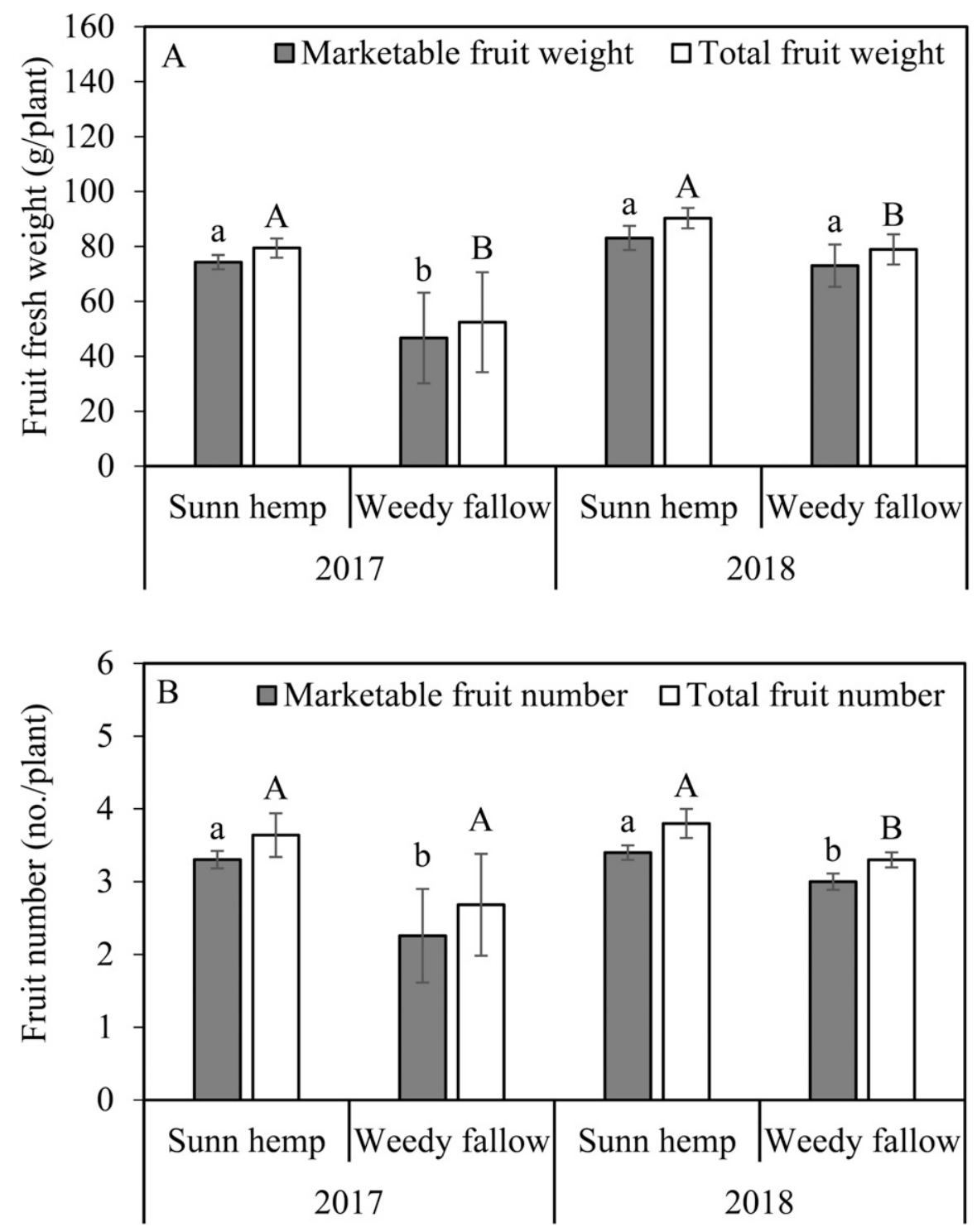

Fig. 5. Organic strawberry early-season marketable and total fruit weight yield (A) and fruit number (B) per plant in sunn hemp and weedy fallow plots in 2017 (December harvests) and 2018 (November and December harvests) in Citra, FL. Error bars represent standard deviations $(\mathrm{n}=4)$. Vertical bars with the same lowercase letters (marketable fruit weight yield or fruit number) or uppercase letters (total fruit weight yield or fruit number) within each year do not differ significantly according to Fisher's least significant difference test at $P \leq 0.05$.

and strawberry transplanting could be shortened to improve the synchronicity between $\mathrm{N}$ release of sunn hemp residues and $\mathrm{N}$ demand by the strawberry crop, especially when containerized transplants are used. A crop with rapid establishment and relatively high $\mathrm{N}$ requirement early in the season could improve the recovery of $\mathrm{N}$ released by sunn hemp. Overall, the use of sunn hemp as a green manure provides opportunities for nutrient management enhancement and innovations in organic cropping systems, although its integration and optimization for a specific system still requires more in-depth studies.

\section{Conclusions}

This study illustrates the potential of AEMs as a reliable tool to monitor in situ study, sunn hemp used as a green manure also exhibited consistent benefits in promoting organic strawberry early-season fruit yield. Besides its use in Florida strawberry cropping systems, sunn hemp is also increasingly grown as a rotational cover crop for vegetable production in both organic and conventional systems. More research is needed to further understand the supply of available $\mathrm{N}$ from sunn hemp residues in meeting $\mathrm{N}$ demand and improving yield performance of subsequent crops in diverse cropping systems, with the goal of improving $\mathrm{N}$ recovery and minimizing $\mathrm{N}$ losses.

\section{Literature Cited}

Abrams, M.M. and W.M. Jarrel. 1992. Bioavailability index for phosphorus using ion exchange resin impregnated membranes. Soil Sci. Soc. Amer. J. 56:1532-1537.

Azeez, J.O. and W. Van Averbeke. 2010. Nitrogen mineralization potential of three animal manures applied on a sandy clay loam soil. Bioresour. Technol. 101:5645-5651.

Baitsaid, A., B. Schaffer, A.I. Vargas, Y. Li, and G. Liu. 2018. Effect of plant age on in-soil decomposition and nitrogen content of sunn hemp tissue. Commun. Soil Sci. Plant Anal. 49:26802688.

Blanco-Canqui, H., M.M. Claassen, and D.R. Presley. 2012. Summer cover crops fix nitrogen, increase crop yield, and improve soil-crop relationships. Agron. J. 104:137-147.

Braz, G.B.P., R.S. Oliveira, W.T. Crow, and C.A. Chase. 2016. Susceptibility of different accessions of Crotalaria juncea to Belonolaimus longicaudatus. Nematropica 46:31-37.

Cherr, C.M., J.M.S. Scholberg, and R. McSorley. 2006. Green manure as nitrogen source for sweet corn in a warm-temperate environment. Agron. J. 98:1173-1180

Cherr, C.M., J.M.S. Scholberg, R. McSorley, and O.S. Mbuya. 2007. Growth and yield of sweet corn following green manure in a warm temperate environment on sandy soil. J. Agron. Crop Sci. 193:1-9.

Dinnes, D.L., D.L. Karlen, D.B. Jaynes, T.C. Kaspar, J.L. Hatfield, T.S. Colvin, and C.A. Cambardella. 2002. Review and interpretation: Nitrogen management strategies to reduce nitrate leaching in tile-drained Midwestern soils. Agron. J. 94:153-171.

Doane, T.A. and W.R. Horwáth. 2003. Spectrophotometric determination of nitrate with a single reagent. Anal. Lett. 36:2713-2722.

Durairaj, S.E. and J.K. Stute. 2018. Sunn hemp: A legume cover crop with potential for the Midwest? Sustain. Agr. Res. 7:63-69.

Elsaid, E. and R. Silva. 2017. Potential of sun hemp residue to provide potato with adequate nitrogen. J. Plant Nutr. 40:851-860

Gaskell, M. and R. Smith. 2007. Nitrogen sources for organic vegetable crops. HortTechnology 17:431-441

Hagesteijn, K.F.L., S. Jiang, and B.P. Ladewig. 2018. A review of the synthesis and characterization of anion exchange membranes. J. Mater. Sci. 53:11131-11150.

Haruna, S.I. and N.V. Nkongolo. 2015. Cover crop managemen effects on soil physical and biological properties. Procedia Environ. Sci. 29:13-14.

Hill, E.C., K.A. Renner, and C.L. Sprague. 2016. Cover crop impact on nitrogen availability and dry bean in an organic system. Agron. J. 108:329-341. 
Jabloun, M., K. Schelde, F. Tao, and J.E. Olesen. 2015. Effect of temperature and precipitation on nitrate leaching from organic cereal cropping systems in Denmark. Eur. J. Agron. 62:55-64.

Johnson, H.J., J.B. Colquhoun, A.J. Bussan, and C.A.M. Laboski. 2012. Estimating nitrogen mineralization of composted poultry manure, organic fertilizers, and green manure crops for organic sweet corn production on a sandy soil under laboratory conditions. HortTechnology 22:37-43.

Kim, H.J. and D. Siegmund. 1989. The likelihood ratio test for a change-point in simple linear regression. Biometrika 76:409-423.

Kumar, K. and K.M. Goh. 2003. Nitrogen release from crop residues and organic amendments as affected by biochemical composition. Commun. Soil Sci. Plant Anal. 34:2441-2460.

Kuzyakov, Y. and X. Xu. 2013. Competition between roots andmicroorganisms for nitrogen: Mechanisms and ecological relevance. New Phytol. 198:656-669.

León Castro, L. and J.K. Whalen. 2016. Ion exchange membranes are sensitive indicators of ammonium and nitrate released from green manures with low C/N ratios. Eur. J. Soil Biol. 77:4-8.

León Castro, L.X. and J.K. Whalen. 2019. Nitrogen supply from green manure enhanced with increased tillage frequency: A note. Agron. J. 111:935-941.

Lindsey, L.E., K. Steinke, D.D. Warncke, and W.J. Everman. 2013. Nitrogen release from weed residue. Weed Sci. 61:334-340.

Maathuis, F.J.M. 2009. Physiological functions of mineral macronutrients. Curr. Opin. Plant Biol. 12:250-258.

Mansoer, Z., D.W. Reeves, and C.W. Wood. 1997. Suitability of sunn hemp as an alternative latesummer legume cover crop. Soil Sci. Soc. Amer. J. 61:246-253.

Masunga, R.H., V.N. Uzokwe, P.D. Mlay, I. Odeh, A. Singh, D. Buchan, and S.D. Neve. 2016. Nitrogen mineralization dynamics of different valuable organic amendments commonly used in agriculture. Appl. Soil Ecol. 101:185-193.

Mohanty, M., K.S. Reddy, M.E. Probert, R.C. Dalal, A.S. Rao, and N.W. Menzies. 2011. Modelling $\mathrm{N}$ mineralization from green manure and farmyard manure from a laboratory incubation study. Ecol. Modell. 222:719-726.

Mulvaney, M.J., C.W. Wood, K.S. Balkcom, D.A. Shannon, and J.M. Kemble. 2010. Carbon and nitrogen mineralization and persistence of organic residues under conservation and conventional tillage. Agron. J. 102:1425-1433.

Nyiraneza, J., A. N'Dayegamiye, M.H. Chantigny, and M.R. Laverdière. 2009. Variations in corn yield and nitrogen uptake in relation to soil attributes and nitrogen availability indices. Soil Sci. Soc. Amer. J. 73:317-327.

Ozores-Hampton, M. 2012. Developing a vegetable fertility program using organic amendments and inorganic fertilizers. HortTechnology 22:743-750.

Qian, P. and J.J. Schoenau. 1996. Ion exchange resin membrane (IERM): A new approach for in situ measurement of nutrient availability in soil. Plant Nutr. Fert. Sci. 2:322-330.

Qian, P. and J.J. Schoenau. 2002. Practical applications of ion exchange resins in agricultural and environmental soil research. Can. J. Soil Sci. 82:9-21.

Rosolem, C.A., G. Castoldi, L.A. Pivetta, and T.E. Ochsner. 2018. Nitrate leaching in soybean rotations without nitrogen fertilizer. Plant Soil 423:27-40.

Schomberg, H.H., N.L. Martini, J.C. Diaz-Perez, S.C. Phatak, K.S. Balkcom, and H.L. Bhardwaj. 2007. Potential for using sunn hemp as a source of biomass and nitrogen for the Piedmont and Coastal Plain regions of the southeastern USA. Agron. J. 99:1448-1457.

Skogley, E.O. and A. Dobermann. 1996. Synthetic ion-exchange resin: Soil and environmental studies. J. Environ. Qual. 25:13-24.

Stallings, A.M., K.S. Balkcom, C.W. Wood, E.A. Guertal, and D.B. Weaver. 2017. Nitrogen mineralization from 'AU Golden' sunn hemp residue. J. Plant Nutr. 40:50-62.

Thorup-Kristensen, K., J. Magid, and L.S. Jensen. 2003. Catch crops and green manures as biological tools in nitrogen management in temperate zones. Adv. Agron. 79:227-302.

U.S. Department of Agriculture, Agricultural Marketing Service (USDA-AMS). 2006. United States standards for grades of strawberries. 31 July 2020. $<$ https://www.ams.usda.gov/sites/default/files/media/Strawberry_Standard\%5B1\%5D.pdf $>$.

U.S. Department of Agriculture, National Agricultural Statistics Service (USDA-NASS). 2017. Certified organic survey 2016 summary. 8 July 2020. <https://www.nass.usda.gov/Publications/Todays_Reports/reports/census17.pdf $>$.

Weatherburn, M.W. 1967. Phenol-hypochlorite reaction for determination of ammonia. Anal. Chem. 39:971-974.

White, P.M., G. Williams, H.P. Viator, R.P. Viator, and C.L. Webber. 2020. Legume cover crop effects on temperate sugarcane yields and their decomposition in soil. Agron. 10:703, doi: 10.3390/agronomy 10050703 .

Yang, J.E., E.O. Skogley, S.J. Georgitis, B.E. Schaff, and A.H. Ferguson. 1991. Phytoavailability soil test: Development and verification of theory. Soil Sci. Soc. Amer. J. 55:13581365 .

Zare, L. and A. Ronaghi. 2019. Comparison of $\mathrm{N}$ mineralization rate and pattern in different manure- and sewage sludge-amended calcareous soil. Commun. Soil Sci. Plant Anal. 50:559-569.

Zhang, J. 2000. Shipboard automated determination of trace concentrations of nitrite and nitrate in oligotrophic water by gas-segmented continuous flow analysis with a liquid waveguide capillary flow cell. Deep Sea Res. Part I Oceanogr. Res. Pap. 47:1157-1171.

Ziadi, N., A.N. Cambouris, and M.C. Nolin. 2006. Anionic exchange membranes as a soil testing for nitrogen availability. Commun. Soil Sci. Plant Anal. 37:2411-2422. 